\title{
Particularities of Political Vocabulary in Tatar and Mari Mass Media: Synchronic and Diachronic Analysis
}

\author{
Flera Ya. Khabibullina ${ }^{1} \&$ Iraida G. Ivanova ${ }^{1}$ \\ ${ }^{1}$ Mari State Univercsity, Yoshkar-Ola, Russia \\ Correspondence: Flera Ya. Khabibullina, Mari State University, Yoshkar-Ola, Kremlevskaya Street 44, \\ Yoshkar-Ola, Mari El, 424000, Russia. Tel: 8-906-335-5882. E-mail: khflora@yandex.ru
}

\author{
Received: February 21, 2015 Accepted: March 15, 2015 Online Published: April 29, 2015 \\ doi:10.5539/res.v7n8p65 URL: http://dx.doi.org/10.5539/res.v7n8p65
}

\begin{abstract}
Politics, like any other social sphere, is served by a distinct system of lexical resources, namely-political vocabulary. The article examines semantical and structural organisation of political vocabulary in two languages - Tatar and Mari-both from a historical perspective and at the present stage of their development. Lexico-semantic groups expressing the concepts of "power" and "politician" are thoroughly explored. The following dominant ways of political vocabulary formation are identified: morphological, morpho-syntactic, lexico-grammatical and phono-morphological. Political lexemes deriving from Altai, Turkic and Tatar strata are investigated. Borrowings in the political vocabulary are carefully examined, data drawn from the leading Tatarand Mari-medium newspapers. The article also covers a study of functioning of the political vocabulary related to the concepts of "power" and "politician", such as: state / country, government, political party / movement, heads of state departments, elections.
\end{abstract}

Keywords: political vocabulary, socio-political vocabulary, system of terms, nucleus, peripherals, synchronous analysis, lexico-semantic classification, structural classification, historical-genetic formation

\section{Introduction}

Questions investigated in this article are essential constituents of a topical problem of language and culture development, enrichment and interaction. The article abides by the theory of contact linguistics. The most significant works in the field of linguistic contacts were carried out by G. Ascoli, H. Schuchardt, J. Baudouin de Courtenay, U. Weinreich, E. Haugen, L. Shcherba, etc. V. Vinogradov, Y. Zhluktenko, N. Mechkovskaya, V. Klokova, A. Molodkin, E. Volodarskaya, G. Bagana should be mentioned among the Russian linguists who focused on the problems of contact linguistics.

Importance of the article is determined by the rising interest towards regional languages in the linguistic society - their lexis and interaction from synchronic and diachronic perspectives; as well as by the absence of a systematic comparative study of the political vocabulary of the Tatar and Mari languages at the present stage of their development.

Tatar and Mari are ancient peoples of the Mid Volga Region. The Tatar language belongs to Kypchak group of Turkic languages. It's occasionally called Bulgaro-Tatar or Volga-Tatar. The language is primarily spoken in Tatarstan, Bashkortostan, Mordovia, Mari El, Chuvashia, Komi, Chelyabinsk, Sverdlovsk and some other regions of the Russian Federation, Central Asia and Azerbaijan.

The Mari language belongs to the Volgaic group of Finno-Ugric family. Other than in the Republic of Mari El, it extends along the Vyatka river basin and eastwards to the Urals: in Tatarstan, Bashkortostan, Udmurtia, Nizhny Novgorod and Sverdlovsk regions. The Mari language of today has four variants: Hill Mari, Meadow Mari, Eastern Mari and Northwestern Mari.

Contacts between Mari and Turkic peoples started in the second half of the first millennium. There were several periods of active language influence and interaction.

Mari first encountered Bulgar people. During almost five centuries the Mari people were a part of Volga Bulgaria. In the XIII-XIV centuries, the Khanate of Kazan occupied the territory, bringing Maris under control (Churikov, 1999). Strong mutual exposure (Turkic and Finno-Ugric) between the Tatar and Mari languages dates back to VIII century. Thus, on the one hand, we can assert that the unified Mari language, formally based on the 
languages of several ancient Mari tribes, was in an intermediate position between Volga and Perm groups of Finno-Ugric language family, subject to a profound effect from Turkic languages. On the other hand, one of the prominent and notable features of Mari-Turkic language contacts was the existence of Mari borrowings - mariisms (a term suggested by N. Isanbaev) — in Turkic languages (Isanbaev, 1989). Later, in the XVI century, Russian influence, especially on the Mari language, became more apparent.

Therefore, historical facts indicate a long-term co-existence of Finno-Ugric and Turkic peoples in the same geographical region, which naturally led to certain changes in their languages and cultures.

Terminology analysis is a major part of contact linguistics studies, particularly for the multi-cultural regions. Due to the significance of language as a means of expressing and transmitting information, more and more attention is currently being paid to extensive and thorough research of separate systems of terms. Rapid development of international relations, openness and mobility of borders result in an increasing linguistic interest in political terminology.

In Russia, political vocabulary research is immediately related to the concept of "socio-political vocabulary". The latter, to a certain extent, is covered in bilingual dictionaries (Russian-Tatar, Tatar-Russian, Russian-Mari, Mari-Russian). However, specialised dictionaries of political vocabulary are quite scarce. Two Tatar publications are particularly worth mentioning - "Political Vocabulary" (Seyasi, 1925) and "Political Dictionary" (Politik, 1958) published in 1925 and 1958 respectively. In the Mari language, political terminology hasn't to date been arranged into any specialised dictionary, but can be found in the Records Management Manual in the Mari language (Ivanov, 2007).

Analyzing socio-political vocabulary, linguists commonly support a unified opinion that there's a clear-cut nucleus within this lexical stratum - a word of strictly political classification — such as "state".

According to L. Muradova, a socio-political vocabulary nucleus can be identified as follows: if a lexical unit contains "political" and "social" components in its meaning, then it can be regarded as an integral part of a nucleus of socio-political vocabulary (Muradova, 1986). Dictionary definitions help to pinpoint these components.

L. Zhdanova distinguishes 4 distinct "zones" at the basis of socio-political vocabulary. The first zone includes socio-political vocabulary itself (in its narrow meaning) - designated names of people, places, concepts, structures constituting political life of society. Zones two to four include ideological, theme-based and "peripheral" terminology (Zhdanova, 1996). All language transformations, according to A. Miniyar-Belorucheva, are evinced on the level of lexical units, in their substantial and functional essence. This phenomenon can be explained by the fact that semantics is a core of language, it contains the "meaning of linguistic creativity" (Miniyar-Belorucheva, 2014).

It's equally complex to determine periphery constituents of socio-political vocabulary, on account of a complicated nature of the very concepts "political" and "social". For instance, L. Muradova characterises the content of the periphery quite comprehensively including lexical units from the fields of economics, diplomacy, culture. State politics covers various spheres of social life since it touches upon most areas of human activity.

Simultaneously, politics is an area directly related to relations among classes, nations, social groups; and the essence of it is the everlasting strive to conquer, retain and use the state power. Political systems of most societies include, along with states, political parties, church, organisations and movements seeking political power and dominance. For that reason, it's evident that both nucleus and periphery of socio-political vocabulary are complex notions, and that the borders of the periphery are relatively conditional.

In contrast to terminology of political science, political vocabulary is attributed to common lexical resources and is used in texts targeting general public. Thus, political vocabulary can be defined as a theme-based combination of commonly used words that need to be understandable for general public.

E. Sheigal states that politics as a specific sphere of human activity is, by its nature, a cluster of speech actions (Sheigal, 2000). Political vocabulary is section-based: in the centre there are "genres" which conform to the fundamental objective of political communication - a strive for power. Those are: parliament debates, political leaders speeches, elections. In peripheral "genres", according to the author, the function of "fight for power" incorporates functions of other types of discourse: juridical, scientific, educational, medical, religious, etc. The author names the two concepts - "power" and "politician"- as fundamental for political vocabulary.

Political vocabulary momentarily reacts to all the changes happening in today's world. Presently, the foreground tendency of its development derives from mobility and cross-cultural dynamics and is demonstrated in intensification of the usage of political borrowings in all the world languages. Causes for borrowings emerging 
in the Russian, Tatar and Mari languages are thoroughly described in the works of I. Krysin, M. Khairullin, S. Sibatrova and other linguists.

\section{Materials and Methods}

Descriptive and classification methods were applied; the latter one incorporating semantic and structural classification of lexical units in the sphere of politics in the Tatar and the Mari languages.

Comparative approach was applied; that allowed to deduce both general principles and specific national features of various political discourses.

The study of political lexemes was based on samples from print media of Tatarstan and Mari El. In the modern age, mass media, especially periodicals, embody the very sector of social development that ensures functioning of political vocabulary. The data were drawn from leading Tatar- and Mari-medium newspapers: Ватаным Татарстан (My Homeland Tatarstan)—socio-political newspaper in the Tatar language, published in Tatarstan; and Марий Эл (Marij El, Mari El) - socio-political newspaper in the Mari language published in the Republic of Mari El, and also newspapers Безнең гажит (Our newspaper) (Tatar) and Акчарлак (Seagull) (Tatar) Кугарня (Friday) (Mari).

\section{Results and Discussions}

A unified system of socio-political vocabulary was established during the final period of the Tatar and the Mari nations genesis (end of XIX - early XX centuries); one of the most significant reasons for that being emergence of periodical press in the discussed languages.

The most significant impact on the process of development of the Mari political vocabulary came from the Tatar language. A large amount of words conveying the meaning of social status and other social concepts finds roots in the Tatar language (Isanbaev, 1978).

Political vocabulary in the Tatar language, hence second-handedly in the Mari language, derives from the four primary historico-genetical strata: 1) Altaic; 2) Turkic; 3) Tatar; 4) stratum of borrowings (Aleeva, 2009). G. Aleeva indicates that the Tatar socio-political vocabulary was organised in a terminological system during the Bulgar period and had Arab-Persian roots.

Standardisation process began during the second half of the XIX century, piquing by the XX century. After 1917, a significant proportion of Russian and Western European borrowings penetrated the Tatar language.

For centuries, these layers were a source of borrowings in the political vocabulary of the Mari language.

Socio-political terms from the Altaic strata are хан, түләү, кабала, etc.

The word $х а н$ "Khan" refers to the title of a ruler for Turkic and Mongolian peoples, as well as the person having this title. In the "Tatar-Russian dictionary" word xat is given with the meaning of "Khan" (hist.) (Tatar-Russian Dictionary, 2002 13, p. 374) and in it is close to the meaning of such words as идарәче "leader", хөкемдар "ruler", "overlord". In the Mari language dictionary the word хан is fixed with the meaning of "Khan"- the ruler of Turkic peoples. Presently, the word retains its meaning and has historico-stylistic connotations.

The lexical unit түләу "payment, remittance" conveys a meaning of giving money or other valuables as a compensation to terminate sth, to void. In the "Tatar-Russian dictionary", the lexical unit түләу possesses two meanings: 1) fee, payment, instalment, remittance; 2) colloquial tax (Tatar-Russian Dictionary, 2002). In the Mari language тӥльммаш (n) from the verb тӥлаш indicates "fee, payment, clearance, remittance" (Dictionary of the Mari language, 2002).

The word кабала (servitude) means: 1) lifelong subserviency due to debt obligations; 2) complete economic dependence of the exploited country. In the Tatar-Russian dictionary the lexical unit "servitude" is given in the sense of "enslaving subserviency"

The lexical unit кабала (servitude) has the following meanings in the Mari language: 1) hist. servitude (slavery). 2) indirect bondage; complete subordination (Dictionary of the Mari language).

The Turkic stratum is a core layer of the Tatar socio-political vocabulary. The following words can be singled out: башльк "head of state" ил "country", киңәш "council", сайлау "elections" copamy "poll", түрә "officer", "public authority representative" жчитәкче "leader", ж⿻и "state", илчелек "embassy “, акча "money “, etc.

Tatar word башльк "head of state" (concept—-"politician", category_-"heads of governing bodies") retains its basic meaning in some dialects of Eastern Meadow, Hill and Eastern dialects of the Mari language (Gordeev, 1983). 
The word ил "country" (concept- "power", category - "state / country") is defined as: 1) the terrain, the area distinguished on the basis of geographical location and natural conditions; 2) the state with a certain governing control (Tatar telenen anlatmali suzlege, 2005). The word itself goes back to the ancient Turkic "tribal alliance, a people, a state". In the "Tatar-Russian dictionary" there are 6 meanings of this word: 1) country; 2) homeland; 3) province; 4) dialect village; 5) people, world, society; 6) adj. worldly, material, mundane (Tatar-Russian Dictionary, 2002). The same meanings of the word exist in the Mari language; the word $и л$ occasionally takes the form of эл.

акча "money" (peripheral genre- -"economics")

Tatar акча "money" means: 1) paper money; 2) capital, wealth. In the Tatar-Russian dictionary the word has three meanings: 1. money, currency; 2. coins; 3 . fund, asset. In the Meadow Mari language dialect, this lexical unit is used in the form of окса with a semantic meaning of "money, banknote" (Tatar-Russian Dictionary, 2002).

Киңзи "council" (concept—-"power", category- "governing bodies")

In the modern Tatar language, this lexical unit functions in the following meanings: 1) meeting; 2) council, an advisory organ.

In the Meadow Mari language dialect киңәш operates in the form of канаш with the meanings of: 1) advice, counsel, recommendation; 2) meeting, gathering, assembly (Dictionary of the Mari language, 1992). Along with the Russian borrowing совет "advice", the lexical unit канаш is contemporarily used to refer to governing bodies: мер канам "public council" самырык кокласе канам "coordinating council", Министр-влак Совет "Council of Ministers".

Сайлаy "elections" (concept—“power", category_-"elections")

Сайлау means "election by ballot." In the Tatar-Russian dictionary, this lexical unit has the following meanings: 1) elections, ballot; 2) recruitment, selection.

The lexeme сайлау is used in the Eastern dialect of the Mari language in its unmodified form: сайлау "elections" (Isanbaev, 1978). As a result of assimilation, the borrowing is used with the suffix— mam in the Meadow dialect: сайльммаш "elections".

TYрә "official, representative of authorities, civil servant" (concept—-"politician", category-“heads of governing structures")

In the ancient Turkic language mYpə used to mean "law", later the meaning altered to "judge", i.e. "defendant of law". In the modern Tatar language it is used in the meaning of "chief, leader". Tatar-Russian dictionary suggests the following meanings: 1) head, official, dignitary; 2) historical judge; 3) colloquial law (Tatar-Russian dictionary, 2002).

The Mari word möpa goes back to the Tatar one mүрә, however, it has a broader meaning than that in the original language: 1) colloquial chief, official; 2) spoken sir, a man belonging to a ruling class; 3) spoken lord, chief; 4) spoken judge, an official at the court (Dictionary of the Mari language Vol. 7, No. 11, 2002, pp. 194-195). As an adjective this word corresponds to the Russian relative adjectives seigniorial, bureaucratic.

Genesis of the Tatar stratum of the political vocabulary concurs with the period of initial formation of the Tatar people (X-XII centuries.). It consists of words existing and formed on the basis of lexical and word formative material of the Tatar language itself.

Relatively ancient vocabulary includes such non-derived words as: үзгәртеп кору "perestroika", шартнамә "contract", торгынлььк "stagnation", яңарыш "renovation, "идарәханд" "board of directors", тархан, ярльккау, чиру, илбашы colloquial "president", илтибәр "prime minister". The Mari language adopted some of those, for example, ярльккау "announcement, decree, command".

The lexemе ярлыкау (peripheral genre- “jurisprudence") means: “1) pardon, absolution, forgiveness, leniency; 2) announcement, decree, command."

In Mari the word ярлькау is fixed in the form ярлькк with the meanings: 1) label, sticker; 2) figurative sobriquet, a stereotypical nickname characterizing someone quite superficially (Dictionary of the Mari language, 2005). As a result of semantic development of the word its meaning was narrowed. The use of such borrowings is determined by a need to create a missing lexical unit to name phenomena.

Among the terms of a later period there are the words that were formed under the influence of political events in people's and the country's life. This group of words was mostly formed through internal resources of the countrywide language. These are suffix and complex words, terms and phrases that are included in the category 
of the analyzed stratum of the Tatar language. For example: зыллль "intellectual", тамгаханд "customs", раслау “approval”, өндәү "agitation, campaigning”, үзгәртеп кору “perestroika”, министрльк “ministry”, etc.

Дәүләтчелек "statehood" from дәүләт (concept_-"power", category_-"governing bodies") — the state system, the state organization (structure).

Тамгаханә “customs" (concept—“power", category- “governing bodies, services”) from maмга-agency which controls import of goods and charges special fees for such an activity. It has recently appeared in the Tatar language as an equivalent of the word customs; in other Turkic languages it is not found.

The lexeme тамга operates in the Mari language as a "brand, label as a sign of ownership" and a "written sign, font, sign" (stamp) (spoken) (Dictionary of the Mari language, 2002).

A certain part of the Tatar political vocabulary consists of early direct borrowings from the Oriental and European languages which were included in the Mari lexical system indirectly through the Tatar language. This happened due to close contacts, exchange of scientific and technological advancements, economic, cultural, political connections.

In the modern Tatar language, the borrowed stratum of political vocabulary is significant. Words related to this layer came from the Arabic, Persian, Russian and other languages. They are direct loanwords. The earliest borrowings are orientalisms - borrowings from the Arabic and Persian languages, which began to penetrate due to Islam adoption in the X century. In the early XX century Tatar periodicals language was a simplified version of the classic ancient Tatar and Ottoman Turkish languages; along with the traditional for the time Arab-Persian borrowings, it included words of both Russian and Western European origin (Minullin, 2012).

In Mari these borrowings appeared via the Tatar language.

Examples from Arabic: дәүләт "state”, хөкүмәт "government," хакимият "power", сәясәт "роlitics”, дөнья "human society, the system of public order", жсәмгыять "society", идарә "governing”, хальљ "population”, милләт "nation", хак "price", казна "treasury" and others.

Дәүләт "state” (concept—“"power”, category_-"state / country")

Дәүләт (Arabic “empire, state") means "a political organization, society, led by a government and its agencies, designed for the protection of the law and the system; a country with such a political system".

The word дәүләт appears in dialectal forms of the Mari language as дӓ̈лӓm, mӓ̈̈лӓm with the meaning "wealth" (Gordeev, 1983).

Хөкүмәт "government" (concept_-"power", category_-"governing bodies")

Хөкүмәт represents the highest executive and delegating public authority exercising direct control of a state.

In the Mari language the word form хӧкӥмӓm is characteristic of the Eastern dialect; with the meaning of "state" (Isanbaev, 1978).

Хальљк "population, nationality, nation" (concept_-"power", category_-"foreign / domestic policy").

Хальљк means "population, inhabitants of a country; state" (from the Arabic "a people").

The lexeme хальљк (Tatar халык, Arabic хӓлак "creation, people) in the Mari language is used in the meanings "population; nationality, nation" and appears in the forms: кальљк, хальљк

Казна (Arabic хәзинә "treasure, trove; treasury) (peripheral genre- “economics") means "amount of financial and other assets of a state"; in the ancient Turkic казнак is "property buried in the ground".

Казна, кажна functions in the Mari language with the meaning of "treasury".

Certain words from the Persian language rooted and adapted in the Tatar language: базар "market; the place for public trade", кәгазь"official written document", дошман "enemy" and others.

Tatar word базар (Persian бāзāp) (peripheral genre-_economics") operates in the Mari language in the form of пазар with the semantics of "fair, market" along with Russian borrowing рынок (рынке). However, the latter one has a broader usage: Тӱнямбал рынке "international market", рынке условий "market condition".

In the Mari language, the Tatar lexeme кәгазь "paper, a formal written document" (concept_-"power", category _ "political and administrative documents") appears in the form кагаз and is used with the following semantics: 1) paper, writing material; 2) paper, a formal written message, document (Dictionary of the Mari language, 1992).

The Farsi word дошман (situational political vocabulary) means "the enemy; the one who is in a state of 
enmity".

Тушман from the Tatar дошман has a wider use in the Mari language. In addition to the first meaning inherited from the source language, this lexeme is functioning in a figurative sense: enemy, evil, obstacle (Dictionary of the Mari language, 2002). In a position of an adjective, тушман expresses such qualities as hostile, inimical: тушиман айдеме "a bad (hostile) person", тушман шӱлыш "hostile attitude".

Synchronic comparative analysis of the political vocabulary of the Tatar and Mari languages allowed to establish theme-based groups in accordance with the basic concepts of political discourse.

The basic concept of "power" is expressed by such lexico-semantic groups as: state / country; state system; national symbols; party / political movements; elections; foreign / domestic policy; governments, government bodies, agencies, departments, institutions. The concept of "politician" comprises: the head of state, heads of government structures (Khabibullina \& Ivanova, 2014).

The concept of "power" is expressed in the Tatar and Mari languages by such lexico-semantic groups as:

state / country (tat. / mar.): ил /эл country, дәуләт / кугыжаныш state, халык / калык people, республика / республик(е) republic;

National symbols (tat. / mar.): байрак / тисте flag, герб / ойып coat of arms, гимн / чапмуро anthem.

Party / political movements (tat. / mar.): берләшмә, союз / ушем union, confederation, үзәк аппарат / рӱдӧ аппарат central office, headquarters, хәрәкәт / толкын movement (political movement);

Elections (tat. / mar.): сайлау(лар) / сайлымаш elections, сайлаучы / йӱклызӧ (йӱклышӧ) voter, сайлау / йӱклымаш ballot;

Foreign / domestic policy (tat. / mar.): килешү / ойпидыш contract, илче / кылъен ambassador, илчелек / кылгудо embassy, килешү, шартнамэ / кӧнымой, соглашений agreement, тышкы политика / весэл политике foreign policy, эчке политика / элкӧргӧ политике domestic policy, карар / пунчал decree, вәкил / ӱшанъен, полномочный представитель plenipotentiary;

Governments (tat. / mar.): утырыш / погын meeting, съезд / съезд congress, хөкүмәт / виктер government, хакимият, власть / кучем power, Дәуләт Собраниясы / Кугыжаныш Погын the State Assembly, Дәуләт думасы / Кугыжаныш Думо the State Duma, жирле идарә / верысе кучем local administration, башкарма комитет / шуктыш комитет executive committee.

The concept of "politician" is reflected in the Tatar and Mari languages in the following lexico-semantic groups:

Head of state (tat. / mar.): башлыкча / вуйлатыше head, илбашы / президент president, хөкүмәт башлыгы / виктер вуйлатыше, виктервуй head of government;

Heads of power structures (tat. / mar.): чке эшләр министры / элкӧргӧ паша министр Minister of Internal Affaires, Home Secretary, чит ил эшләре министры / йотэл паша министр Minister of Foreign Affaires, сәламәтлек саклау министры / тазалык аралыме шотышто министр Minister of Health, сәүдәт министры / торгайыме шотышто министр Minister of Trade.

Based on the structural classification of socio-political vocabulary, the following types of words can be distinguished in the modern Tatar and Mari languages: a) simple and b) complex. By simple we understand root words and derived words formed by suffixes; by complex words - compound and composite.

Root words (tat. / mar.): ил / эл country, чик / чек border (state border), жир / мланде native land, халык / калык people, эш / паша work, казна / казна treasury, акча / окса money, кыл (mar.) communication, relation, устав / урман statute.

Words formed by affixes (tat. / mar.): гражданлык / гражданлык citizenship, тынычлык / тыныслык world, ирекле / эрыкле autonomous, әшче / пашазе working, депутатлык deputative.

Paired compound words (tat. / mar.): хисап-сайлау / отчётно-выборный reported, elected, ваш-кыл (mar.) cooperation, development of bilateral relations, мер-политике (mar.) social, социаль-экономик, ижтимагый-экономик / социал-экономике socio-economic, мораль-политик / мораль-политике moral and political, гореф-гадэт (tat.) habitude.

Complex words (tat. / mar.): узидарə / шкевиктем self-government, урынбасар / алмашвуй deputy, халыкара (tat.) international, узбилгеләну (tat.) self-determination, хезмэттэшлек (tat.) cooperation, ончылъен (mar.) leader, сомылшуктызо ончылъен (mar.) executive, ачамланде (mar.) fatherland, йотэл (mar.) abroad, виктемвуй (mar.) manager, ӱшанъен (mar.) authorized representative, proxy. 
Compound words are formed mostly by adjoining two components: сайлап алу (tat.) select, яулап алу (tat.) conquest, conquer, тавыш биру (tat.) election, vote, идарә иту (tat.) leadership, эш хакы (tat.) salary, кутырен келшыме (tat.) contract.

Fairly well-developed system of political lexemes formed by various ways of word-formation suggests the availability of means and patterns for such formation.

In both languages the following methods of formation of political vocabulary were discovered: morphological (affixation, simplification), morpho-syntactic (formation of compound words), lexico-grammatical (conversion), phonetic-morphological (abbreviation).

Word formation by suffixes is a prevalent type of formation. The most common suffixes include: -лык / -лек (tat.), -лык (mar.); -че / -чы (tat.) / че, -зе, -зо, зӧ (mar.); -ле (tat., mar.) and other (tat., mar.): законлылык / тӧртыклык legality, киңәшче / канашче counsellor, шуктызо (mar.) executive, пашаче (mar.) figure (representative), йӱклызӧ (mar.) voter, эрыкле (mar.) autonomous.

By simplification we understand words that have lost their primary structure so that, in the modern language, their stems and affixes are not prominent, i.e. they have become whole words impossible to be divided into constituent morphemes: ирек / эрык liberty, өлкә (tat.) area, сайлау (tat.) elections, карар (tat.) decree, тавыш voice, оньыжа (mar.) Chairman of the Mari Council.

Formation of compound words is a productive way of word formation. In both languages, there are quite numerous examples of the words formed according to the following models: $\mathrm{N}+\mathrm{N}, \mathrm{N}+{ }^{\wedge}+\mathrm{N}, \mathrm{N}+\mathrm{V}, \mathrm{V}+\mathrm{N}, \mathrm{Adj}+\mathrm{V}$, $\operatorname{Adj}+\mathrm{N}, \mathrm{N}+\mathrm{V}, \mathrm{N}+\mathrm{V}^{\wedge}$, Pron $+\mathrm{N}$, etc: массакулэм (tat.) universal, шартнамэ (tat.) contract, тавыш биру (tat.) ballot, башкала capital, алмашвуй (mar.) deputy, виктемвуй (mar.) manager, сомылъен (mar.) official, вишйўклымаш (mar.) open-source voting, шкевиктем (mar.) autonomy, вуйвер (mar.) presidium.

Conversion, or lexico-grammatical method of creating political vocabulary, can be demonstrated on the examples of zero formation of nouns on the basis of verb forms (infinitive, participle, etc.)

Tatar: сайлау vote, elections, өндәү agitate, agitation, өндәүче agitating, agitator, килешү agreement, agree (come to a consensus, comply), сайлаучы voting, voter, кабул иту accept, acceptance.

mar.: вуйлатыше (вӱдышӧ), leader, leading, алмаштыше deputy, substituting, acting, погынышо attendees, серкалыше (возкалыше) secretary, writing, йӱклышӧ voter, voting, виктарыше manager.

At the present stage of language development the number of abbreviations is increasing drastically. For the languages under discussion, there's a characteristic change-from abbreviation borrowings to abbreviations formed on the basis of language potential itself.

Tatar: ТР-Татарстан Республикасы The Republic of Tatarstan, БДБ-Бәйсез дәутләр бергәлегә CIS (Commonwealth of Independent States), ЭЭМ-эчке эшләр министрлыгы Ministry of Home Affairs, БМО-Берләшкян Милләтләр Оешмасы UN, АКШ-Америка кушма штатлары USA, ТИУ-Татар ижтимагай узәгә the Tatar Public Center, БУБК-Бөтенроссия узәк Башкарма All-Russian Central Executive Committee, ФМХ - Федераль миграция хезмэте FMS (Federal Migration Service).

Mari: МЭР-Марий Эл Республик Mari El Republic, РP-Республикысе рӱдер Resource Centre, ЭПМ-Элгкорго паша министрестве Ministry of Home Affaires, ЙПМ-Йотэл Паша Министерстве Ministry of Foreign Affairs, МТ-Муниципал Тӧнеж Municipal Administration, ФАС-Федерал Аралтыш Службо FSB, УНО-Ушнышо Наций-влак Организаций $U N$.

Sources of abbreviation emergence are both internal resources of languages and borrowings from the Russian language with their subsequent adaptation (tat. / mar.): РФ-Россия Федерациясы / Россий Федераций the Russian Federation.

Loanwords occupy a special place in the Tatar and the Mari languages. They come into the languages in a fixed form, but assimilate accoding to the rules of receiving languages (tatar / mari): халык / калык nation, population (Arabic); базар / пазар market, кәгазь / кагаз official letter, document (Persian); федерация / федераций federation, республика / республик republic, конституция / конституций constitution, президент / президент president, губернатор / губернатор governor, депутат / депутат delegate, декларация / деклараций declaration, референдум / референдум referendum, диктатура / диктатур dictatorship, цензура / цензур censorship (Latin); автономия / автономий autonomy, демократия / демократий democracy, кризис / кризис crisis, система / системе system, идеология / идеологий ideology (Greek); муниципалитет / муниципалитет municipality, парламентаризм / парламентаризм parliamentarism, путч / путч putsch, лозунг / лозунг slogan, саммит / саммит summit (German); министр / министр minister, премьер-министр / премьер-министр рrime 
minister, мэр / мэр mayor, дипломатия / дипломатий diplomacy, peформа / peформа reform, партия / партий party, комитет / комитет committee, революция / революций revolution (French); митинг / митинг mass-meeting, rally, брифинг / брифинг briefing, лидер / лидер chief инаугурация / инаугураций inauguration, бойкот / бойкот boycott, импичмент / импичмент impeachment (English); газет / газет newspaper, мемориал / мемориал memorial (Italian); флаг / флаг flag (Dutch); регламент / регламент regulations, by-laws, standing orders, ратуша / ратуш town hall (Polish) and others.

The study of the functioning of the modern political vocabulary in regional languages was carried out in accordance with the basic concepts of political discourse_- "power" and "politician."

Lexico-semantic group state / country is reflected in the nomenclatural names of territories, territorial confederations.

Drastic changes in the political life of the Soviet Union led to the emergence of Russian Federation, the Republic of Tatarstan and the Republic of Mari El on the world map. Consequently the political vocabulary of the Tatar and Mari languages acquired the following lexical units:

Tatar: Россия Федерациясы, Маri: Россий Федераций “Russian Federation”; Tatar: Татарстан Республикасы (Татарстан) "the Republic of Tatarstan (Tatarstan)", Mari: Марий Эл Республика (Марий Эл) “the Republic of Mari El'”.

E.g.: Tatar: Татарстан Республикасы Дәүләт Советы карары. "Decree of the State Council of the Republic of Tatarstan";

Mari: Тиде кечылаште Марий Элымм вуйлатыше Йошкар-Оласе сервис технологий-влак техникумын тунемме да туныктымо пашаж дене палыме лийын. "The president of the Republic of Mari El familiarised himself with the study process at the College of Service and Technologies, Yoshkar-Ola."

The renewed word stock, on the one hand, reflects the new content of previously known concepts (region, district, autonomy), on the other hand, it fixes the newly emerging territorial and political institutions (CIS, EU).

Mari: Тушко (студент-влакын VII тунямбал конференцийыш) Российысе 54 вуз да СНГ гыч 170 наре участник чумырген (Mari El, No. 59). “Around 170 participants from 54 Russian and CIS universities attended the VII International Student Conference".

Tatar: АКШ, Канада, Евросоюз артыннан, кичә Австралия дә Россиягә карата санкцияләр кертүен белдерде (Shehri Kazan, No. 30). "Yesterday Australia, following the USA, Canada and the European Union, has announced imposing sanctions on Russia."

Tat.: “Бурятия татарларының милли-мәдәни автономиясе: тарихы, формалаушы, үсеш перспективалары” дигән китап денья күрде (Vatanym Tatarstan, No. 18-19). “A new book has recently been published-“National and cultural autonomy of Tatar peoples of Buryatia: history, formation and prospects of growth."

Mari: Национально-культурный автономий-влак шотышто федеральный законын илышыш шындаралт толмыжо жотышто Мер Канаш вуйверын енже А.Радыгин (Удмуртий) радамлен (Mari El, No. 56-57). "Chairman of the Public Council A. Radygin (Udmurtia) presented a report on the implementation of the federal law regarding national and cultural autonomies."

Tatar: Татарстан авыллары юкка чыга. (...). Идел буе федераль округында әлеге курсәткеч—44, ә Россиядә 58 процентны тәшкил итә (Vatanym Tatarstan, No. 18-19). "Tatarstan villages disappear. (...) The percentage shows $44 \%$ in the Volga Federal Region, and 58\% nationwide."

Mari: A тиде жапыште “Йошкар-Ола” ола округын администрацийжын промышленность, транспорт, связь да предпринимательстве отделже (...) конкурсым увертарен (Mari El, No. 56-57). "Meanwhile the Department of Industry, Transportation, Communications and Business of the administration of the city of Yoshkar-Ola “(...) has announced a competition.”

Tatar: (...), регионнарның икътисади хәле, үзек hәм жирле массакүләм мәгълүмат чараларында житәкче эшчәченлегенең яктыртылуы, (...) тикшерелгән (Akcharlak, No. 5). “(...) activities of leaders of regional, central and local entities were touched upon (...)".

Mari: 27-28 мартыште Йошкар-Олаште, Марий Элын Мер-политике рӱдерыштыже, “Марий форум: шошо сессий” регион-влак кокласе конференций эртен (Mari El, No. 56-57). “On March, 27-28 the Interregional conference was held in the Socio-Political Center of the Republic of Mari El; the topic was "Mari forum: Spring Session".

The names of political and ideological trends and their members should be attributed to the lexico-semantic 
group of party / political movements; e.g.: national separatists, nationalists, neo-fascists, pluralists, etc.

Mari: (...) неофашист, националист-влакын торжалыкыштлан мучаш огеш кой (Mari El, No. 48). “(...) no end to acts of violence by neo-fascists and nationalists."

Despite the fact that "pluralism, pluralists" had long been recorded in dictionaries, they were introduced in a new meaning by Mikhail Gorbachev during perestroika - existence of many equal opinions.

Tatar: Дин өлкәсендә демократия, плюрализм-шактый куркыныч нәрсә (Vatanym Tatarstan, No. 59). "Democracy and pluralism in religion-quite a dangerous notion."

High frequency of use of the names of parties, movements and their participants leads to occasional lexical neologisms:

Tatar: Бүгенге илбашы кем ул? Реформатормы, бер яктан икенче якка чайкалу-тайпылуларны булдырмаучы “стабилизатор” мыл, әллә соң эллеккегә ябышып ятучы консерватормы? (Vatanym Tatarstan, No. 18-19). "The head of state today: who is he? A reformist, an inept, rushing from side to side "stabilizer", or a conservator clinging to the past?"

The political background of the modern world is largely affected by religious activities. Hence political vocabulary is constantly being updated (Wahhabi, Jihad, Mujahideen), for example:

Tatar: Студентлар арасында ваһhабчыммазарлар күренсә, алларны шунда ук куып чыгаралар (Vatanym Tatarstan, No. 59). “As soon as students adopt Wahhabism, they are immediately expelled."

The names of electoral and related technologies have enlarged the political vocabulary of the former Soviet Union: lobbyists, populism, rating, referendum, electoral, electorate. e.g.:

Tatat: Бер көндә-ике референдум (Vatanym Tatarstan, No. 59). “За день-два референдума”. (...) Американың “The New York Times” газетасы, Кырымдагы референдум Россия салдатларының күзәтүе астында үткән, дип яза (Shehri Kazan, No. 30). “Two referendums a day.” (...)

The American newspaper "New York Times" wrote that the referendum in the Crimea was held under a careful surveillance of Russian soldiers."

Mari: Тудо (Общероссийский митинг) Крымыште эртыше референдумын лектышыже негызеш Крымым да Севастопольым Россий составыш пуртымо йодыш дене кылдалтын (Mari El, No. 48). “The All-Russian rally was inspired by the results of the referendum concerning joining of the Crimea and Sevastopol to Russia."

The word "rating" means "position of a politician based on a comparative assessment", and is an indication of popularity of people among their own kind.

Tatar: Peйтингта беренчелеккә 95 балл жыйган Ямал-Ненец автономияле округы губернаторы Дмитрий Кобылкин чыккан (Akcharlak, No. 5). "According to the rating, the first place was taken by the Governor of the Yamal-Nenets Autonomous Okrug Dmitry Kobylkin with the total score of 95 points."

Mari: “Тӱнямбал рейтинг-2013” медиасообществын иктешлымашыж почеш, икымше номеран политиклан РФ президент В.Путиным шотлымо (Mari El, No. 46-47). “According to the media group "International Ranking 2013", Vladimir Putin, president of the Russian Federation, is recognized as the most popular politician."

The nomenclatural names of political and administrative departments reflect the concept of "power" and are included in the category of "governing bodies". Here we can distinguish such lexemes as: the Parliament, City Hall, municipality, prefecture, the Duma, the Cabinet of Ministers, and police.

Tatar: Кичә дүртенче чакырылыш ТР Дәүләт Советы депутатлары, язгы сессияне ачып, парламентның 37 нчы утырышын уздырды (Vatanym Tatarstan, No. 18-19). "Yesterday the members of the State Council of the fourth convocation of the Republic of Tajikistan, opened a new spring session with the 37 session of Parliament."

Mari: Конгресс полатыште Кугыжаныш Погынын “Марий Элыште мер контроль практике нерген” теме дене парламент колыштмашыже эртен (Mari El, No. 58). "Parliamentary hearing of the National Assembly on "The practice of social control in the Republic of Mari El" was held in the Palace of Congresses".

Tatar: Административ хокук бозулар турында Россия Федерациясе кодексына үзгәрешләүр кертү хакында федераль закон проектын Россия Федерациясе Федераль Собраниесе Дәүләт Думасына кертү буенча Ставрополь крае Думасының закон чыгару инициативасы турында (Vatanym Tatarstan, No. 18-19). “On enforcing new amendments to the Federal Assembly of the State Duma regulation on administrative offences by 
the initiative of the Duma of Stavropol Territory".

Mari: Нуным тыгак РФ Кугыжаныш Думын депутатше Л. Яковлева саламлен (Mari El, No. 56-57). “Тhey were also congratulated by L. Yakovleva, the member of the State Duma of the Russian Federation."

Tatar: Шуннан соң күргәзмә кысаларында Министрлар Кабинетында узган киңәшмәдә 2013 елда энергияне сак тоту өлкәсенда республика программасын тормышка ашыру йомгаклары һәм быелга бурычлар буенча фикер алышу булды (Vatanym Tatarstan, No. 39). "Later on, in the framework of the meeting at the Cabinet of Ministers the formal ideas exchange on the implementation of the republic-wide energy-saving program for 2013 and the tasks for the current year took place."

Normally, official executive bodies on the city-level are called: "administration of the head of the city", "city hall", "the government of the city", "city administration."

Tatar: Узган ел бу “бүләк”кә Казан мериясы һәм “Электрон хөкүмәт” лаек булган иде (Vatanym Tatarstan, No. 59). "Last year, the Town Hall of Kazan and "Electronic government" deserved this "gift".

Mari: Тӥшка мероприятийым эртарымылан кора 12 гыч 13 шагат марте Ленин проспектын Советский ден Первомайский урем коклаже чыла тӱрлӧ транспортлан петырыме лийеш,-увертарышт Йошкар-Ола мэрийын пресс-службыштыжо (Mari El, No. 56-57). "Due to the mass events from 12:00 to 13:00, the access for all types of vehicles will be restricted from Lenin Avenue to Sovetskaya St. and Pervomayskaya St. - the city hall of Yoshkar-Ola press office announced."

Mari: Талантан икшыве-шамычым Морко районысо депутат-влак погынымашым вуйлатыше С. Иванова, районысо администраций вуйлатышын алмаштышыже-влак саламленыт (Марий Эл, No. 59). “Talented children were congratulated by S. Ivanova, Morkinsky District deputy of the head".

The new names appeared for the former authorities of the Soviet period, for example, the militia was renamed the police, KGB-FSB:

Tatar: Полищия хезмәткәрләре ялганчыны эзләү белән мәшгуль (Vatanym Tatarstan, No. 18-19). "The police are busy looking for a fraudster".

Mari: Кодшо кечылаште марий полицийын сводный отрядше Сочи гыч пӧртылын (Mari El, No. 59). "Last week, the combined police squad returned from Sochi."

Tatar: (...) анда бик күп полиция, ФСБ һәм Казан шәһәре башкарма комитеты хезмәткәрләре тора (Akcharlak, No. 5). "(...) a lot of police, the FSB and the representatives of the executive committee of Kazan were present".

The concept of "politician" fits into the lexico-semantic group of the head of state, head of government structures and is widely used in the nomenclatural names of persons: the President, the Prime Minister, Deputy Prime Minister, the Speaker, the Mayor, etc.

The borrowed word "president" is nowadays firmly set in both languages under the influence of extralinguistic factors, despite the fact that in the pre-perestroika period it was used mainly in reference to heads of foreign states, such as the US President, the French president:

Tatar: Татарстан Президенты "the President of Tatarstan"; Mari: Марий Элын Президентше "Тhe President of Mari El Republic".

Tatar: Татарстан Республикасы Президенты Рөстәм Миңнеханов Токио шәһәнә (Япония) ике көнлек эш визиты белән килде (Chehri Kazan, No. 30). "The President of the Republic of Tatarstan, Rustam Minnehanov, arrived with a business visit for two days in Tokyo (Japan)."

Mari: РФ Президентын Йошкар-Оласе приемныйыштыжо 2014 ий апрельыште ен-влак дене вашлийме график (Mari El, No. 59). "Schedule of citizens' appeals to the office of the President of the Russian Federation in Yoshkar-Ola in the April 2014".

Numerous names of the heads of governing bodies has changed. Such words as the Mayor, the Prime minister, the Prefect, etc. appeared in the vocabulary.

Tatar: Мәскәу өлкәсенең Красногорск шәһәренда РФ Премьер-министры Дмитрий Медведев рәислегендә Россия Гражданнар оборонасы һәм гадәттән тыш хәлләр министрлыгы житәкчелеге, гражданнар оборонасы көчләренең гомумроссия жыены булды. Чарада Татарстан Премьер-министры Рөстәм Миңнеханов катнашты (Vatanym Tatarstan, No. 18-19). "The meeting of Russian Civil Defence and the Ministry of Emergency Situations was held in Krasnogorsk, Moscow region, chaired by the Prime Minister Dmitry Medvedev. The Prime Minister of Tatarstan, Rustam Minnehanov, participated in the meeting." 
Presently, the word Mayor is the official title of a chief executive in the cities of Kazan and Yoshkar-Ola.

Tatar: Мэр Ильсур Метшин да, докладта китерелгән мәгълүматларга карата үфикерен белдереп: “(...) "(Chehri Kazan, No. 30). "The Mayor Ilsur Metshin also expressed his opinion on the issues raised in the report: (...)".

Mari: Шке жапыштыже Йошкар-Олан мэрже, Сомбатхейыште 5-ше №--ан поликлиникын у зданийжым почын (Mari El, No. 59). "At the time, the Mayor of Yoshkar-Ola opened a new building of Hospital No. 5 in the Szombathely community."

A greater part of borrowed political vocabulary in the mass media penetrates into regional languages; in most cases it has English origin. For instance, many anglicisms are taken to refer to those concepts which have not been previously mentioned in the dictionaries of the Tatar and Mari languages. They are, to some degree, the "only" ones possible (meeting, briefing, speaker, leader, sanction, etc.).

Tatar: Кырым татарлары лидеры Мостафа Жәмилевка 2019 елга кадәр Россия территориясенә керу тыелган (Vatanym Tatarstan, No. 59). "The leader of the Crimean Tatars, Mostafa Dzhamilev, has been denied entry on the territory of Russia."

Mari: Йуклымышын икымше результатше пале лиймеке (...) Верховный Советын спикерже В. Константинов каласен (Mari El, No. 48). "After the preliminary elections results, the Speaker of the Supreme Council V. Konstantinov (...) announced."

Tatar: Митингка чыгучылар 16 январьда Югары Рада кабул иткән законнарга каршы (Akcharlak, No. 5). "Mass meeting participants protested the adoption of the laws by Verkhovna Rada on January, 16."

Mari: Кодшо рушарнян Йошкар-Олаште, Оболенский-Ноготков плошадьыште (...) митинг лийын (Mari El, No. 68). "The meeting (...) took place on the Obolensky-Nogotkov square in Yoshkar-Ola last Sunday".

\section{Conclusion}

Political vocabulary in the Mari and Tatar languages is a sufficiently developed and orderly system. It serves as the core of the socio-political word stock. The vocabulary under discussion reflects two basic concepts- "power" and "politician"- and is represented by the following lexico-semantic groups: a state / a country, the state symbols, parties / political movements, elections, foreign / domestic policies, governing bodies; the head of state, heads of government structures.

The structure of the Tatar and Mari political vocabulary is formed according to the general classification criteria. The structural and semantic equivalence of the studied units indicates their linguistic relevance in terms of comparative analysis. Political vocabulary of the Tatar, as well as the Mari languages uses not only the external resources but also the internal ones. The following methods of word formation are represented in both languages: affixation (by suffixes), compounding, abbreviation and conversion. In both languages, morphological derivation is the most productive way of word formation. Morphological derivation reflects specific characteristics of each of the languages. Loan words predominantly coincide in their meanings as well as in their formal features.

Political vocabulary of the languages in contact-Tatar and Mari-goes back to the four historico-genetic strata: Altaic, Turkic, Tatar and the stratum of borrowings. One should mention the predominant tendency to form new Mari political lexemes on the basis of the existing Tatar ones. The fundamental lexical units related to public and political systems in the Tatar and Mari languages are of the Turkic origin. They are concentrated around two basic concepts:"power" and "politician".

According to the results of the study, it can be stated that the process of borrowing political vocabulary in regional languages is determined by the changes in global politics, actualization of new political realities which the Tatar and Mari languages lack adequate definitions for or the existing designated units have changed their semantic-functional status.

The modern political vocabulary of the Mari and Tatar print media can be characterised by its unification, international nature, universalisability and tendencies towards standardisation.

\section{Acknowledgements}

The authors of the article express gratitude for the translation into English to Natalia Egoshina, ESL instructor at Elite English, Beijing, China (精英英语, 北京, 中国).

\section{References}

Abdullin, I. A., Ganiev, V. A., Mukhamadiev, M. G., \& Yunaleeva, R. A. (2002). Tatar-Russian dictionary: 250000 words. Kazan Tatar publishing house. 
Abramova, A. A. et al. (1992). Dictionary of the Mari language. Yoshkar-Ola: Mari Publishing House.

Abramova, A. A. et al. (2005). Dictionary of the Mari language. Yoshkar-Ola: Mari Research Institute.

Aleeva, G. U. (2009). Socio-political vocabulary of the Tatar language (Autoreport of the Philology Candidate). Kazan.

Churikov, I. A. (1999). Mari pedagogy: A Handbook for students of pedagogical institutions. Yoshkar-Ola: Mari State Pedagogical Institute.

Ganieva, F. A. (2005). Explanatory Dictionary of the Tatar language. Kazan.

Gordeev, F. I. (1983). Etymological dictionary of the Mari language. Yoshkar-Ola: Mari publishing house.

Isanbaev, N. I. (1978). Lexico-semantic classification of Tatar loanwords in the Mari language. In Questions of the Mari language (pp. 3-50). Yoshkar-Ola: Mari Research Institute.

Isanbaev, N. I. (1989). Mari-Turkic language contacts—Part One (Tatar and Bashkir borrowings). Yoshkar-Ola: Mari Book Publishing House.

Ivanov, I. G. (2007). Records Management Manual in the Mari language. Yoshkar-Ola: Ministry of Culture, Media and Ethnic Affairs.

Khabibulina, F. Y., \& Ivanova, I. G. (2014). Borrowed political vocabulary in the Tatar and Mari languages: Historical and genetic reservoirs. Theory and Practice, 36(6), 184-187.

Khabibulina, F. Y., \& Ivanova, I. G. (2014). Functioning of the modern political loanwords in Tatar and Mari print media. Theory and Practice, 37(7), 200-204.

Khabibulina, F. Y., \& Ivanova, I. G. (2014). Political vocabulary in the Tatar and Mari languages: Synchronical analysis. Theory and Practice, 31(1), 186-190.

Khayrullin, M. B. (2001). Foreign words in the East-West context-Essays on the history of the Tatar culture (pp. 573-588). Kazan: Ficker.

Krysin, L. P. (1994). Foreign words in the context of contemporary social life. Russian language at school, 6 , 56-63.

Minullin, B. K. (2012). Arab-Persian and Turkish borrowings in the Tatar language periodicals at the beginning of the 20th century. Theory and Practice, 17(6), 99-101.

Minyar-Belorucheva, A. P. (2014). Semantics is a Language Core. Modern communication study, 3(6), 63-65.

Muradova, L. A. (1986). Semantic and functional characteristics of the socio-political vocabulary of the modern French language. Moscow: Nauka.

Ponomarev, B. N. (Ed.). (1958). Political Dictionary. Kazan: Tatar publishing house.

Sheigal, E. (2000). Semiotics of political discourse. Volgograd: Peremena.

Sibatrova, S. S. (2013). On some changes in the vocabulary of the Mari language. Mari world, 2, 46-61.

Zhdanova, L. A. (1996). Socio-political vocabulary: Structure and Dynamics (The dissertation of the Phylilogy Candidate), Moscow.

\section{Copyrights}

Copyright for this article is retained by the author(s), with first publication rights granted to the journal.

This is an open-access article distributed under the terms and conditions of the Creative Commons Attribution license (http://creativecommons.org/licenses/by/3.0/). 